\title{
Creating Comfortable Classroom by VAK Learning Styles: Planning for Early Childhood to Interest in Learning English
}

\author{
Lista Litta ${ }^{1}$, AstryBudiarty ${ }^{2}$ \\ listalitta91@gmail.com \\ ${ }^{1}$ Engineering Faculty, Universitas Teknologi Sulawesi, Makassar, Indonesia \\ ${ }^{2}$ Social and Political Sciences Faculty, Universitas Teknologi Sulawesi, Makassar, Indonesia
}

Received: 30 October 2020 Accepted: 01 December 2020

DOI: $10.24256 /$ ideas.v8i2.1659

\begin{abstract}
The objectives of the research were to investigate whether or not creating a comfortable classroom by VAK learning styles as a technique has significant effects for early childhood in learning English and whether or not the students are interested in creating a comfortable Classroom by VAK Learning Styles as a technique in Learning English. This research employed a pre-experimental method by using one group pre-test and post-test design, where the writer did an experiment in a single group only. The population of this research was the students of TK Tri Putri in Makassar Suburb academic year 2019/2020. This research used purposive sampling. The sample consisted of 34 students. Those students should be 5-6 years old. The data was collected by using a writing test and observation checklist. The findings showed that there was an improvement in the students' English ability after the treatment. The students' result of the posttest was more significantly improved than the students' result of the pretest by the mean score of $81.18>$ 50.12. The difference of both scores was statistically significant based on the t-test value at significant level 0.05 in which the P-value is lower than the significant level $0.000<$ 0.05). The mean score of the students' interest in cycle 2 was 80 and it was categorized as interested classification.
\end{abstract}

Keywords: Comfortable Classroom; Interest, Learning English, VAK Learning Styles.

\section{Introduction}

Teaching English to Young Learner (TEYL) becomes so popular today since the needs of facing globalization era. In addition, teaching English for Young Learner is very important for preparing students to be ready and well-prepared generation to be met with the future demand like communication and technology. 
ISSN 2338-4778 (Print) ISSN 2548-4192 (Online)

Now, most of schools in Indonesia insert English as subject in curriculum even in early childhood level. Early childhood according to NAEYC (National Association for the Education of Young Children) in Aisha (2011: 1) is the children who are in the age range 0-8 years, which is included in educational programs in the park child care, child care in the family (family and child care home), education either private or public preschool, kindergarten, and elementary school. Kindergarten level for some children is the first stage in learning through informal situation. Here, children learn how to interact with the knowledge and also social life. Kindergarten is also the place to stimulate the children in developing their language skill. However, some students are afraid of learning English. In another side, some teachers are also afraid to teaching English. English looks like a very high level of subject, so that some people choose the other subject to be mastered.

Nowadays, English is being one of the compulsory subjects in most of kindergarten school in Indonesia including in Kindergarten School in Makassar Suburbs. Based on the interview conducted on $17^{\text {th }}$ July 2019 to a teacher at TK Tri Putri in Makassar Suburbs, the teacher said that the students had problem in studying English. They are less interested in learning English because they think English is difficult. Whereas, Rosmayasari (2010) stated that the new learning depends upon interest. It means that learning cannot occur unless the person is interested in learning. Syatir (2011) also stated that interest could give more motivation to the students to use their ability. It means, the students will work harder if they are strongly interested in doing something than if they are not.

Referring to the case above, the researchers decided to create a comfortable classroom with Visual, Auditory Kinesthetic (VAK) Learning Styles that have significant effect in Learning English and might be interesting for the students. Considering, decorating a classroom with some kind of warmth can help promote a sense of comfort and security especially from childhood. Huda (2014) states that VAK learning model is multisensory learning style that engages three learning styles namely seeing, listening and moving. In other word, VAK Learning model is learning style that combine three sensory modalities to absorb information, lesson and knowledge by seeing, hearing and moving, which helps students to learn through more than one the senses and they can learn easily, faster to improve their achievement in the teaching learning process. It is supported by Weiberg (2009) who states that "we can use the VAK model to enhance our teaching, as long as we remember that our students are individuals with unique ways of taking in and retrieving information". In addition, Ramdian, Chayono \& Suryati (2019) who found that the VAK learning model succeeded in helping the students to improve their writing' achievement. Ginting (2017) demonstrated that learning styles (Visual, Auditory, and Kinesthetic) and ways of thinking contribute to effective teaching. Hardina and Suyata (2018), on other hand, conducted that the VAK model is effective in learning of summary writing. Meanwhile, Bakri, Rahman, Jabu \& Jasruddin (2019) also pointed out that the adoption of the VAK learning style can 
improve the English speaking skills and the methodology can be used as a preliminary strategy to assess students' learning capability.

Damayanti (2018) in their research study revealed that there was significant influence of using VAK Learning Model toward students' narrative text writing ability. Rafida, Ramadhan \& Chatimah (2018) pointed out that there was significant influence of the students' achievement in writing short story text were taught by using VAK (Visual, Auditory, Kinesthetic) learning model. Meanwhile, Litta, Atmowardoyo, \& Salija (2015) also pointed out that there was a significance difference before the treatment and after the treatment by Visual Auditory Kinesthetic Learning Style.

Previous researches showed that Visual Auditory Kinesthetic Learning Style as a technique was an effective in improving students' writing and speaking ability. In contrast, this method is rarely implemented to teach English in generally for early childhood. Young learners have a great curiosity to try new things. They enjoy learning through playing. If the learning is fun, automatically children language skill will develop significantly.

Related to the background, the researchers formulated research questions are (1) does VAK learning styles as a technique has the significant effects for early childhood in learning English? and (2) are the students interested with creating comfortable Classroom by VAK Learning Styles as a technique in learning English?. Meanwhile the objectives of the research were to investigate whether or not creating comfortable classroom by VAK learning styles as a technique has the significant effects for early childhood in learning English and whether or not the students are interested with creating comfortable Classroom by VAK Learning Styles as a technique in Learning English. Consequently, in this research the researchers will apply the VAK learning styles with creating comfortable classroom to enhance the English ability especially for early childhood. Hopefully, this learning style can give a positive impact on students' interest in studying English as well as in improving English ability.

\section{Method}

\section{Research Design}

This research used pre-experimental method by using one group pre-test and post-test design, where the writer did an experiment in a single group only. The pre-test was given to find out the students' basic achievement and posttest was given to find out the effectiveness of creating comfortable class by VAK learning styles for early childhood in learning English. In other hand, the researchers used observation checklist as the instrument to identify the students' interest in comfortable Class by VAK learning styles in learning English.

\section{Population \& Sample}

The population was the students of TK Tri Putri in Makassar Surburb 
academic year 2019/2020. The sampling technique used is purposive sampling in which 34 students are taken as sample. Those students should be 5-6 years old.

According to Black (2010), purposive sampling is a non-probability sampling method and it occurs when the elements selected for the sample are chosen by the judgment of the researcher. Researchers often believe that they can obtain a representative sample by using a sound judgment. It means the sample was chosen based on the criteria the researcher wanted.

\section{Research Instrument \& Procedure of Collecting Data}

The researcher used two kinds of instruments in collecting data namely writing test and observation checklist. Writing test consist of pre-test and post-test. Besides, in order to get a supporting data about the students' interest, the researcher used observation checklist. In collecting the data, the writer applied the following procedures:

1. The researcher gave check in the observation checklist (Pre cycle) before employed pre-test.

2. Before giving treatment, the researcher employed pre-test to the students. (1 meeting)

3. After pre-test, the researcher employed treatment for students with Creating Comfortable Classroom by VAK Learning styles for 10 meetings. Then the researcher's partner did observation checklist during the teaching and learning proses (cycle 1 and cycle 2).

4. After the treatment, the researcher employed post-test to find out the students' achievement and their progress. (1 meeting)

5. The researcher analyzed the collected data.

Technique of Data Analysis

In analyzing the collecting data through writing test and observation checklist, the researcher used the procedures below:

\section{Writing Test}

In this research, the data was collected after giving instruments of collecting data from students. The data was analyzed through quantitative analysis by calculating the mean score and standard deviation of the students' achievement by using SPSS version 22.After collecting the data, the researchers assessed and analyzed the students' test results using the final score category provided in table 1 as follow: 
Creating Comfortable Classroom by VAK Learning Styles: Planning for Early Childhood to Interest in Learning English in Makassar Suburb

Table 1. The final score category

\begin{tabular}{cc}
\hline Range of Final & Scores Category \\
\hline $86-100$ & Very Good \\
$71-85$ & Good \\
$56-70$ & Fair \\
$10-55$ & Poor \\
\hline
\end{tabular}

(Adapted from Abbas, 2015, 2018)

\section{Technique of analyzing data from the Observation Checklist}

The researcher uses observation checklist during the teaching and learning process in preliminary research, cycle I and cycle II. Observation checklist is used to make the observation process easier. In observation stage, the researcher is helped by the teacher/her partner in observing what happen in the class during the lesson from opening until closing. In this research, the concern of research was focused on the students' observable behavior pertaining to their understanding in Learning English in Comfortable class by VAK Learning Style. The observation checklist is used as an instrument in this research. The researcher gave check in the observation checklist, and then the students' interest can be classified as follow:

Table 2. Interest classification

\begin{tabular}{cc}
\hline Score & Classification \\
\hline $85-100$ & Strongly interested \\
$69-84$ & Interested \\
$53-68$ & Moderate \\
$37-52$ & Uninterested \\
$20-36$ & Strongly uninterested \\
\hline & (Sugiyono, 2008)
\end{tabular}

\section{Results}

The Analysis Data of the Students' English Ability

a. Scoring Classification of Students' Pre-test and Post-test

Regarding with the findings explained previously, it shows that the English ability of the students of TK Triputri in Makassar Surburb with Creating Comfortable Classroom by VAK Learning Styles was improved. It is supported by the students' frequency and rate percentage of the students' pretest and posttest result. Before conducting the treatment, the researcher gave a pretest to know the prior knowledge of the students in English. After treatment, the students got the posttest. The pretest and posttest were compared to know the students' English ability and then the frequency and percentage of the students were firstly tabulated. Afterwards, the researcher classified the quality of the students' English 
ability score of pre-test and post- test in table 3 below:

Table 3. The Rate percentage of Student's Score of Pre-test and Post-test

\begin{tabular}{|c|c|c|c|c|c|}
\hline \multirow{2}{*}{ Classification } & \multirow{2}{*}{ Score } & \multicolumn{2}{|c|}{ Pre-test } & \multicolumn{2}{|c|}{ Post-test } \\
\hline & & Frequency & Percent & Frequency & Percent \\
\hline Very Good & $86-100$ & 0 & 0 & 10 & 29,4 \\
\hline Good & $71-85$ & 1 & 2,9 & 17 & 50 \\
\hline Fair & $56-70$ & 15 & 44,1 & 7 & 20,6 \\
\hline Poor & $10-55$ & 18 & 53 & 0 & 0 \\
\hline Total & & 34 & 100 & 34 & 100 \\
\hline
\end{tabular}

The rate scoring classification of students' pre-test and post-test can be shown in the following diagram:

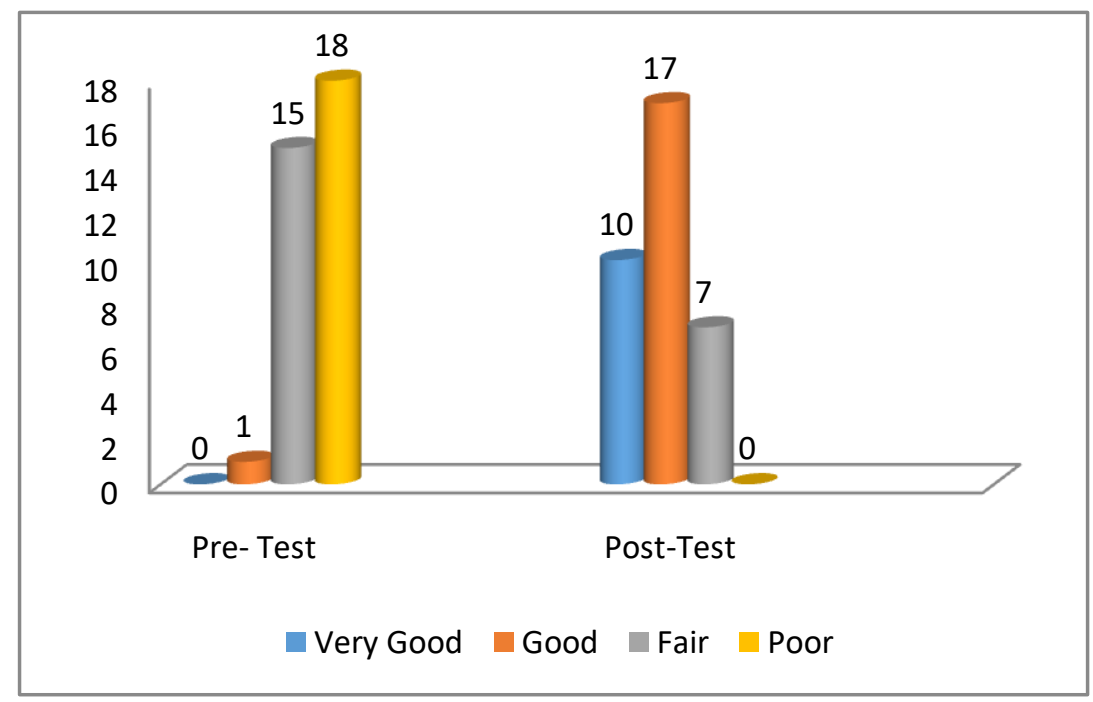

Figure 1. Scoring Classification of Students' Pre-test and Post-test

Based on the table 1 and figure 1, it is known that most of the students' pretest results fell into very poor classification. They were 18 (53\%) students who got poor classification, 15 (44.1\%) students who got fair classification, 1 (2.9\%) student who got good classification and none of them who got very good classification. However, in the post-test result, it can be found 10 (29.4\%) students who got very good classification, 17 (50\%) students who got good, 7 (20.6\%) students who got fair classification and none of them who got poor classification. It means that the classification in the students' post-test result was better than the classification in the students' pre-test result. Therefore, creating comfortable classroom by VAK learning styles in learning English was effective to improve the student's English ability. 
Creating Comfortable Classroom by VAK Learning Styles: Planning for Early Childhood to Interest in Learning English in Makassar Suburb

\section{b. Mean Score and standard deviation of Students' Pre-test and Post-test}

The distribution of the score of the students' English ability in post-test shows a difference from the pretest. After conducting the treatment, the student's English ability showed an improvement. The mean score and standard deviation of the students' English ability in pre-test and post-test are shown in table 4 and figure 2 below:

Table 4. The Mean Score and Standard Deviation of Students' EnglishAbility in Pre-test and Post-test.

\begin{tabular}{ccc} 
Group & Mean Score & Standard Deviation \\
\hline Pre-test & 50.12 & 14.65 \\
Post-test & 81.18 & 11.59
\end{tabular}

Table 2 show that the mean score of post-test is higher than the mean score of the control group, (81.18 > 50.12). 81.18 is classified as good category. While, 50.12 is classified as poor category. This means that creating comfortable classroom by VAK learning styles was applied in learning is more successful to increase the students' English ability. The results of the students' improvement in pre-test and post-test are shown in figure 2 .

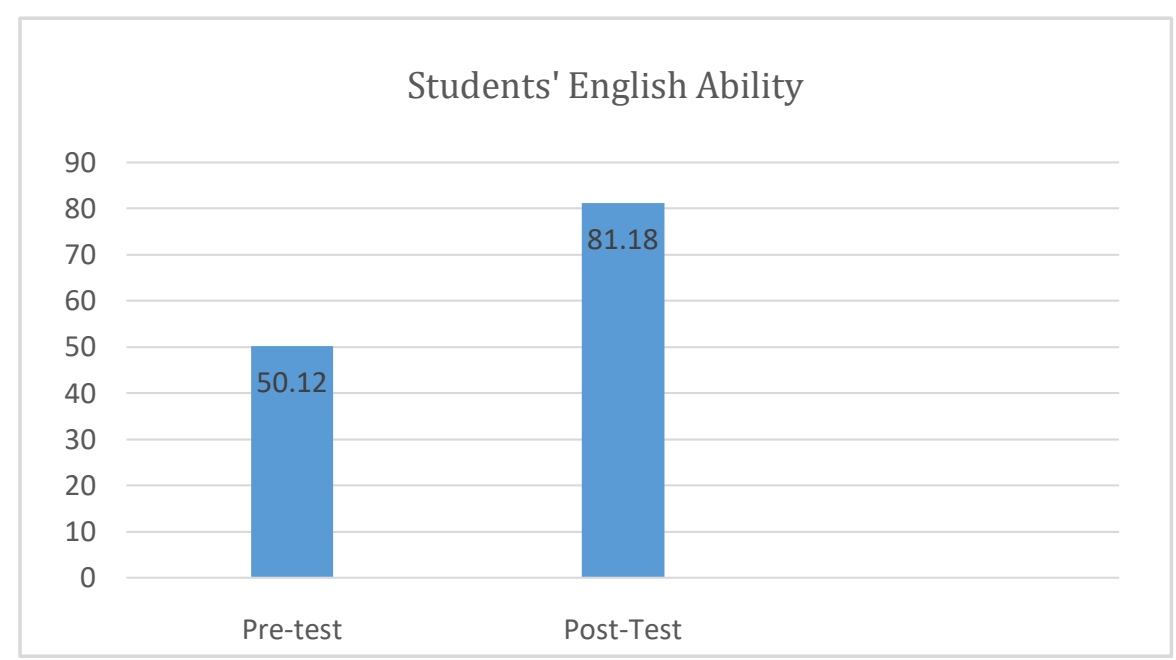

Figure 2. The students' improvement in pre-test and post-test

\section{c. Test of Significance (T-test)}

The result of t-test was calculated by using SPSS version 22. After using the statistics, the researcher found the probability value of t-test as presented in the following table 5 . 
Table 5. $\quad$ Significance Different

\begin{tabular}{|c|c|c|c|c|c|c|c|c|c|}
\hline & & \multicolumn{5}{|c|}{ Paired Differences } & \multirow[b]{3}{*}{$\mathrm{t}$} & \multirow[b]{3}{*}{$\mathrm{df}$} & \multirow[b]{3}{*}{ Sig. (2-tailed) } \\
\hline & & \multirow[b]{2}{*}{ Mean } & \multirow{2}{*}{$\begin{array}{c}\text { Std. } \\
\text { Deviation }\end{array}$} & \multirow{2}{*}{$\begin{array}{c}\text { Std. Error } \\
\text { Mean }\end{array}$} & \multicolumn{2}{|c|}{$\begin{array}{c}\text { 95\% Confidence } \\
\text { Interval of the } \\
\text { Difference }\end{array}$} & & & \\
\hline & & & & & Lower & Upper & & & \\
\hline Pair 1 & $\begin{array}{l}\text { PRE TEST - } \\
\text { POST TEST }\end{array}$ & -31.05882 & 14.03230 & 2.40652 & -35.95493 & -26.16272 & -12.906 & 33 & .000 \\
\hline
\end{tabular}

Based on table 3 the researcher found that the probability value or p-value $(0.000)$ was smaller than the level of significance $\alpha(0.05)$ or $0.000<0.05$. It is assumed that there is significant difference between the students' English ability improvement after the treatment. The students' English ability of posttest is significant. The students who were treated through creating comfortable classroom by VAK learning style got higher score than before treated. In other word, it can be concluded that Creating Comfortable Classroom by VAK Learning Style as a technique have significant effects for Early Childhood in Learning English.

\section{Students' Interest}

In accordance with the finding, it shows that the students' interest of TK Tri Putri in Makassar Suburb was improved in learning English with creating comfortable Classroom by VAK Learning Styles. The students' responses in learning English was categorized as interested after treatment. The results of the students' interest in learning English with creating comfortable Classroom by VAK learning stylesare shown in table 6 below:

Table 6. The Percentage of Students' Interest

\begin{tabular}{cccc}
$\begin{array}{c}\text { Students' } \\
\text { Interest }\end{array}$ & Pre cycle & Cycle 1 & Cycle 2 \\
\hline Mean Score & 40 & 62 & 80
\end{tabular}

Based on the observation result, the mean score of pre cycle activities is 40 . It means that the students' Interest of pre cycle was uninterested. They were still confused in learning English without creating comfortable classroom by VAK learning styles. While the mean score of students' interest when the researcher implemented creating comfortable classroom by VAK learning styles as a technique in learning English was improved. The mean score of the students' interest in cycle one is 62 and 80 in cycle two. It means that the students' interest 
Creating Comfortable Classroom by VAK Learning Styles: Planning for Early Childhood to Interest in Learning English in Makassar Suburb

of cycle one was moderate and cycle two was interested. It also shows that there were improvements of students' interest in each cycle after learning English with creating comfortable classroom by VAK learning styles. The details the can be seen in figure 3.

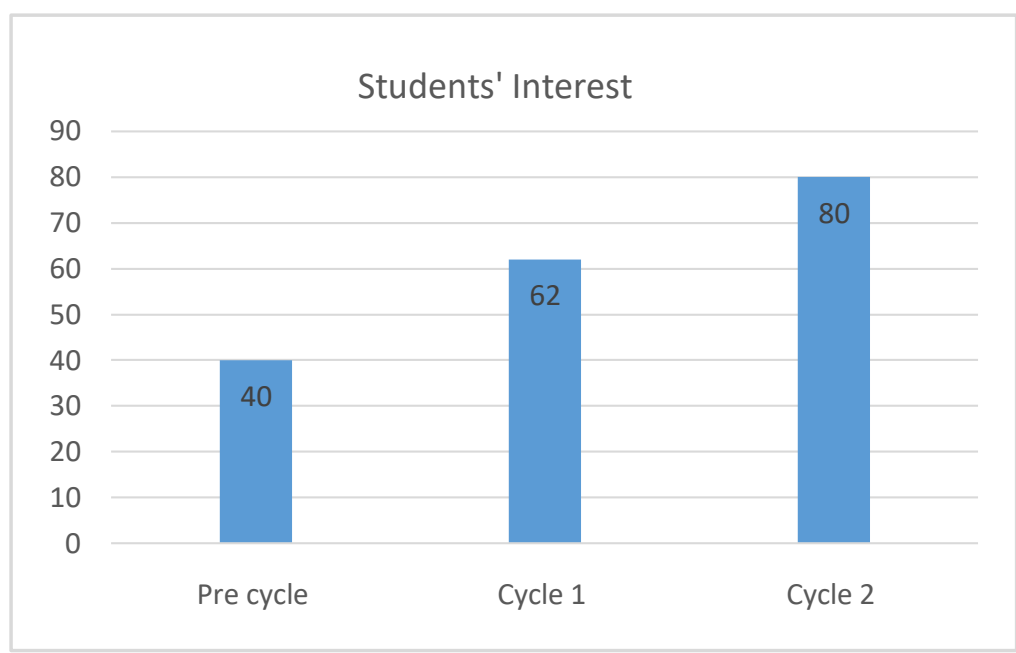

Figure 3. The Percentage of Students' Interest

Furthermore, after analyzing between the result of the students' English ability and the students' interest in learning English with creating comfortable classroom by VAK learning styles, it can be assumed that the creating comfortable classroom by VAK learning styles is more applicable, effective, and useful to increase the students' English ability and the students' interest. It is proven by the mean score of the students in post-test which was 81.18 as categorized as good classification, while the mean score of interest in cycle 2 was 80 as categorized as interested classification.

\section{Discussion}

The Students' English Ability

Regarding with the findings explained previously, it shows that the students' English ability of TK Tri Putri improved in the experimental group. It is supported by the students' frequency and rate percentage of the students' pretest and posttest result. The students score with Creating Comfortable Classroom by VAK learning styles in learning English was better than before treatment. Based on the result of data analysis, it can be found that the students' English ability after treatment by using VAK learning style in the experimental group was better than the students' English ability in control Group.

In addition, the description of the data collected through SPSS version 22 also shows that the students' English ability with creating comfortable classroom by VAK learning styles increased significantly. It is proved by the mean score rate of the result of the students' pretest and posttest. The mean score of the students' 
pretest and posttest was 50.12 and 81.18, while standard deviation was 14.65 and 11.59. In pretest, there were 18 (53\%) students who got poor classification, 15 (44.1\%) students who got fair classification, 1 (2.9\%) student who got good classification and none of them who got very good classification. Meanwhile in posttest, there were $10(29.4 \%)$ students who got very good classification, 17 (50\%) students who got good, 7 (20.6\%) students who got fair classification and none of them who got poor classification (table 3). It can be inferred that the students' posttest is higher than the students' pretest. For these findings, it can be concluded that the score of the students had improved after creating comfortable classroom by VAK learning styles.

The finding above relates to the research by Ramdian, Chayono \& Suryati (2019) who found that the VAK learning model succeeded in helping the students to improve their writing' achievement. The result of this study implies that VAK learning model can be an alternative to improve the students' writing skill. In addition, another research finding which also supports this research finding is a research conducted by Ginting (2017). He demonstrated that learning styles (Visual, Auditory, and Kinesthetic) and ways of thinking contribute to effective teaching. Hardina and Suyata (2018), on other hand, conducted about "The Effectiveness of VAK (Visual, Auditory, Kinesthetic) Model in Learning of Summary Writing". The results revealed that the VAK model is effective in learning of summary writing. Meanwhile, Bakri, Rahman, Jabu \&J asruddin (2019) also pointed out that the adoption of the VAK learning style can improve the English speaking skills and the methodology can be used as a preliminary strategy to assess students' learning capability.

Based on the students' result obtained and stated in finding and in discussion above, the researcher used t-test in inferential statistics trough SPSS version 22 program to test the hypothesis. Based on statistic test result in table 3 , it shows that probability value is lower than alpha $(\alpha)(0.000<0.05)$. It means that there was a significance difference before the treatment in pretest and after treatment in posttest. In other word, there is an improvement on the students' English ability after the treatment. These findings were in line with some previous research done by Damayanti (2018), Rafida, Ramadhan \&Chatimah (2018)and Litta, Atmowardoyo, \&Salija (2015).

Damayanti (2018) in their research study revealed that there was significant influence of using VAK Learning Model toward students' narrative text writing ability at the second semester of the eighth grade at SMPN 3 Bukitkemuning North Lampung in the academic year of 2017/2018. Rafida, Ramadhan \&Chatimah (2018) about "The Influence of Using VAK (Visual, Auditory, Kinesthetic) Model on the Students' Achievement in Writing Short Story Text at Second Grade SMP IT Al-Hijrah 2 Deli Serdang" pointed out that there was significant influence of the students' achievement in writing short story text were taught by using VAK (Visual, Auditory, Kinesthetic) learning model. It meant 
alternative hypothesis (Ha) was accepted and null hypothesis (Ho) was rejected. Meanwhile, Litta, Atmowardoyo, \&Salija (2015) in their research about "The Effects of Visual Auditory Kinesthetic Learning Style as Technique in Improving Students' Writing Ability" also pointed out that there was a significance difference before the treatment and after the treatment by Visual Auditory Kinesthetic Learning Style. The students' result of posttest of experimental group was more significantly improved than the students' result of posttest of control group. It means VAK learning style had positive effect in improving students' writing ability.

Finally, the researcher concludes that creating comfortable classroom by VAK learning styles as a technique is effective in improving students' English ability.

\section{The Students' Interest with Creating Comfortable Classroom by VAK Learning Style}

In accordance with the finding, it shows that the students of TK Tri Putri in Makassar Surburb were interested in learning English with creating comfortable classroom by VAK learning styles. The mean score of students' interest in cycle two is 80. It mean the students' interest in cycle two was categorized as 'interested'.

The result (figure 3) shows that the mean score of the pre cycle activities is 40. It means that the students' interest of pre cycle was uninterested. They were still confused in learning English without creating comfortable classroom by VAK learning styles. While the mean score of students' interest when the researcher implemented creating comfortable classroom by VAK learning styles as a technique in learning English was improved. The mean score of students' interest in cycle one is 62 and 80 in cycle two. It means that the students' interest of cycle one was moderate and cycle two was interested.From these findings, it can be inferred that the students are interested in learning English with creating comfortable classroom by VAK learning styles.

Furthermore, after analyzing between the result of the students' writing achievement and the students' interest in learning English with creating comfortable classroom by VAK learning styles, it can be assumed that creating comfortable classroom by VAK learning styles is more applicable, effective, and useful to increase the students' English ability and the students' interest. It is proven by the mean score of students in post-test which was 81.18 as categorized as good classification, while the mean score of the students' interest in cycle 2 was 80 as categorized as interested classification.

\section{Conclusion}

Creating comfortable classroom by VAK learning styles was effective to improve the students' English ability. It is proved by the mean score of the students' post-test and pre-test which were significantly different. The mean score of the students' posttest was higher than pre-test. It can be seen from the students' mean score of posttest was 81.18, while for the students' mean score of pre-test was 50.12. The T-test of the students' English ability in pre-test and post-test was 
ISSN 2338-4778 (Print) ISSN 2548-4192 (Online) significantly different. The inferential statistics supports this statement is which p-value $0.000<0.05$. It is assumed that there is significant difference between the students' English ability improvement after the treatment.

The students' interest was high interest to learn English with creating comfortable classroom by using VAK learning styles. It was proved by the mean score of students' interest of the observation check list in cycle two was 80 categorized as interested classification.

Based on the conclusion above, the researcher put some suggestions and recommendation. In teaching English especially in teaching early childhood, the teacher should be more creative for preparing their teaching English material. They can creating comfortable classroom by VAK learning styles as a technique to improve the students' English ability. The teacher should give some enough opportunity and more chance for the students to practice their ability in learning English by using VAK learning styles because it is easier to practice and enjoyable for students. The researcher also recommend that the teacher should give the various techniques in teaching English especially for early childhood based on the students' interest and need. To attract the students' attention, the teacher should be more creative in managing the class, so the students are fun and enjoyable in learning and teaching process.

\section{Acknowledgement}

In this part, the researchers need to express many thanks to the persons who helped in the research. First, the researchers would like to say thank to Ministry of Research, Technology, and Higher Education of Republic of Indonesia (KEMRISTEKDIKTI RI) who gave financial support. Second, the researchers also would like to say thank to LPPM and team of Universitas Teknologi Sulawesi, Makassar-Indonesia who provided good service for the researchers during the research. At last, the appreciation goes to the research assistants, headmaster and teachers of TK Tri Putri in Makassar Surburb who supported totally during the research.

\section{References}

Abbas, M. F. F., \& Herdi, H. (2018). Solving the Students' Problems in Writing Argumentative Essay through Collaborative Writing Strategy. English Review: Journal of English Education, 7(1): 105-114.

Abbas, M. F. F. (2015). Analysis of students' ability in writing a research proposal. Journal ELT-Lectura, 2(2): 44-48.

Aisyah, Siti. (2011). Perkembangan dan Konsep Dasar Pengembangan Anak Usia Dini. Jakarta: Universitas Terbuka.

Bakri, R. A., Rhaman, M. A., Jabu, B. \& Jasruddin. (2019). Exploring the Impact of VAK Learning Style on Teenager Level Language Learners in Indonesia. Journal of Language Teaching and Research, 2(4), 807 - 814.

Black, K. (2010). Business Statistics: Contemporary Decision Making. Cambridge: $6^{\text {th }}$ edition, John Wiley \& Sons. 
Lista Litta \& Astry Budiarty

Creating Comfortable Classroom by VAK Learning Styles: Planning for Early Childhood to Interest in Learning English in Makassar Suburb

Damayanti, E. (2018). The Influence of Using Visualization Auditory Kinesthetic (VAK) Learning Model Toward Students' Narrative Text Writing Ability at The Second Semester of The Eighth Grade at SMPN 3 Bukitkemuning North Lampung in the Academic Year of 2017/2018. Online Thesis. Lampung: Universitas Islam Negeri Raden Intan Lampung. (http://repository.radenintan.ac.id/4638/1/SKRIPSI\%20ERVINA.pdf,

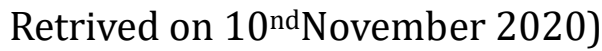

Ginting, S. A. (2017). A Facilitating Effective Teaching through Learning Based on Learning Styles and Ways of Thinking. Dinamika Ilmu, 17(2): 165 - 173.

Hardina, M. T. A. N. \& Suyata, P. (2018). The Effectiveness of VAK (Visual, Auditory, Kinesthetic) Model in Learning of Summary Writing. International Journal of Research \& Review, 5(8): 43 - 49.

Huda, Miftahul. (2014). Cooperative Learning: Metode, Teknik, Struktur Dan Model Penerapan. Yogyakarta: PustakaPelajar.

Litta, L., Atmowardoyo, H., \&Salija, K. (2015). The Effects of Visual Auditory Kinesthetic Learning Style as Technique in Improving Students' Writing Ability. ELT Worldwide, Journal of English Language Teaching, 2 (2) : 62-76.

Munawir, A. (2019). Online Game and Childrens's Language Behavior. IDEAS: Journal on English Language Teaching and Learning, Linguistics and Literature, 7(2). doi:https://doi.org/10.24256/ideas.v7i2.1050

Musliadi, M. (2019). When and How Do Children Start Producing A Languge?. IDEAS: Journal on English Language Teaching and Learning, Linguistics and Literature, 7(2). doi:https://doi.org/10.24256/ideas.v7i2.1032

Oxford University. (2019). Oxford Living Dictionary. Oxford University Press.

Ramadian, O. D., Cahyono, B. Y. and Suryati, N. (2019). The implementation of visual, Auditory, kinesthetic (VAK) learning model in improving students' achievement in writing descriptive texts. English Language Teaching Educational Journal, 2(3), 142-149

Rafida, T., Ramadhan, A. \&Chatimah, A., N. (2018). The Influence of Using VAK (Visual, Auditory, Kinesthetic) Model on the Students' Achievement in Writing Short Story Text at Second Grade Smp It Al-Hijrah 2 Deli Serdang. Journal of Language, Literature \& Education, 13(13). ISSN: 2086-4213.

Rosmayasari. (2010). The Interest of the First Year Students of SMP ISLAM DARUL HIKMAH MAKASSAR in Learning English Using Cartoon Films. Makassar. Unpublish Thesis.

Sugiyono. (2008). Metode Penelitian Pendidikan (PendekatanKuantitatif, Kualitatif, dan R\&D). Bandung: Alfabeta.

Weinberg, D. (2009). Using Learning Style for More Effective Teaching. (online). (https://mydoghasclass.com/docs/resource-list/Weinberg ND09.pdf.

Retrieved on $15^{\text {nd }}$ August 2019). 